\title{
Mentoring Quality in the On-the-Job Learning of PPP: Mentees' Perspectives
}

\author{
Ferayanti M., Sunardi", Siswandari, Akhyar M. \\ Faculty of Teacher Training and Education, Universitas Sebelas Maret, Indonesia
}

Received May 10, 2020 ; Revised June 20, 2020; Accepted July 7, 2020

Copyright $\bigcirc 2020$ by authors, all rights reserved. Authors agree that this article remains permanently open access under the terms of the Creative Commons Attribution License 4.0 International License

\begin{abstract}
Integration of mentoring program in Principal Preparation Program (PPP) is an effective way to develop prospective school principals. This study aims to portrait mentoring supports from mentors in the On-the-Job Learning (OJL) of PPP from perspectives of mentees and to reveal areas of mentoring which need improvement. The study utilized group interviews for data collection as it was a follow-up study of Education Sector Analytical and Capacity Development Partnership (ACDP) 2016. Three-semi structured group interviews were conducted with mentees from Central Java consisting of 20 primary school and 10 secondary school prospective principals. Thematic analysis was used to code the data and to identify themes. The study revealed that mentoring supports for mentees of PPP need improvement. Mentors, especially those of primary schools, need to improve their professional knowledge and mentoring skills to optimize the learning of mentees. Too many activities and tight schedule of the mentors, especially those in secondary schools hampered them to scaffold mentees' learning. The study findings informed the urgency to design and to run training for mentors to improve their practices in mentoring prospective school principals. Further research on mentoring can expand this study because the respondents of this study were not representative of the overall population of prospective principals. Besides, similar studies can be conducted with prospective principals whose mentors are alumni of training for school principals, assuming that mentoring quality might be better since they have attended an 8-day training for school principals.
\end{abstract}

Keywords Mentoring, Mentees, Mentors, Prospective Principals, Principal Preparation Program, On-the-Job Learning

\section{Introduction}

Principal Preparation Program (PPP) has long become the attention of educational stakeholders in the world. Orr and Orphanos [31] found that the quality of PPP would give a positive impact on improving school quality and school climate. This reported research was strengthened with varies of researches confirming that school principals who are well prepared positively contributed to the improvement of students' achievements [4,32,38]. Unfortunately, not all PPPs were able to create good principals $[9,40]$. Some critics of PPP revealed that the leadership programs were isolated from the community [24]); the theory was not integrated with practice $[14,16]$ ) and the PPPs failed to scaffold learning, especially off-the-job and on-the-job training $[14,16]$.

In Indonesia, the PPP training is regulated in the Ministry of Education and Culture number 6 year 2018 and Guidelines from General Director of Teachers and Educational Personnel number 26017/B.B1.3/Hk/2018, which consists of In-service Learning 1 (IN-1), On-the-Job Learning (OJL), and In-service Learning 2 (IN-2) in which time allocation of IN-1 is 70 hours, OJL is 200 hours, and IN-2 is 30 hours. The training model is designed to provide experiential learning in which theories and empirical experience of adult learning are integrated. IN-1 is a face-to-face training program in which prospective principals discuss and learn competencies and tasks of a school principal. OJL is a vehicle to practice competencies and tasks of school principals learnt in IN-1. IN-2 is a phase in which the training participants present their OJL reports and power point of OJL.

Mentoring program is integrated into the OJL, in which they are to learn from 2 principals while implementing the OJL tasks. This policy is in line with Le Comte and McClelland [22] arguing that mentoring is a vehicle to develop leadership especially for those who are inexperienced in leadership. Mentoring is one of the most common approaches for professional support for aspiring and practicing school leaders [33]. There is evidence that mentoring which is integrated in leadership programs has a 
significant impact on leadership efficacy especially when there is strong confidence from mentors and mentees, and the mentees are open to critical feedback $[3,24]$.

The evaluation of Education Sector Analytical and Capacity Development Partnership (ACDP) 2016 found that the OJL was considered 'very effective' by more than half of the participants in PPP (56\%), but respondents in this study did identify some issues with its operation. The principals (mentors) and staff in the schools into which the PPP participants were located for the OJL receive no training about how to support the incoming PPP participants. Some participants in the PPP reported poor responses to their arrival at their nominated host school for the 'on-the-job' part of their professional learning. Yet, this study did not explore further why the mentors needed training. What kind of supports that they failed to give to mentees? What areas of the mentoring supports need improvement? Therefore, as a follow up of the ACDP, this research was conducted. This research, which is part of a doctoral study, aims to analyze and to portrait principals' mentoring in the OJL of PPP from the perspectives of the mentees in order to reveal what mentoring supports the mentors gave to mentees during the OJL, and which areas of mentoring need improvement.

\section{Materials and Methods}

This research was conducted following ACDP 2016 research report. The ACDP aimed to analyze Principal Preparation Program Implementation as a whole from recruitment, administrative selection, academic selection, training IN-ON-IN, and the issuance of certificate. The ACDP study involved 31 districts in 14 provinces in the regions of Sumatra, Java, Kalimantan, Nusa Tenggara-Bali, Sulawesi, Maluku and Papua. Research data were obtained through surveys, interviews and Focus Group Discussions (FGD). Yet, since it did not specifically focus on mentoring OJL, the data on mentoring quality were not well elaborated. The report only mentioned that the implementation of mentoring was not optimal and recommended mentoring training for mentors.

To elaborate mentoring supports given in the process of the OJL, further qualitative research was conducted. The data were collected through semi-structured group interviews in order to elicit the experiences and perceptions of individual participants [6].

The respondents of the group interviews involved 30 volunteering prospective principals from the Central Java region, consisting of 20 primary schools and 10 secondary schools.

The data were collected through taped three 45-minute group interviews of 10 mentees. Each session consisted of 10 prospective school principals (5 females and 5 males). The interviews were conducted in 2019 in Surakarta in which IN-2 training was held.

Group interview was chosen since it can observe the dynamics of group interaction and the process of reality construction and how a view emerges. Further, it can also provide a shared view that can produce richer responses because they give participants the opportunity to argue with one another [11]. However, Lewis, in Denscombe [11] also reminded the problem in group interviews that the arguments that were presented tend to be accepted arguments. Respondents on the group who have different opinions would remain silent, not express their opinions or even choose to adjust their views of the arguments received. To avoid this happening, the researcher tried to explore arguments that might not have been submitted with exploratory questions.

All interviews were recorded. Voice recorder has the advantage of being a permanent recorder and can record sound to completion. Voice recorders also make it easier for researchers to check and repeat interviews. Yet, voice recorders only capture speech but cannot record non-verbal communication and other contexts. Therefore, in addition to voice recorders, notes were also used when conducting interviews. These notes included the content of the interview as well as feelings and non-linguistic data [39].

The interviews were then transcribed and analyzed via thematic analysis [6]. This analysis is appropriate to identify and to log patterns and generating themes from respondent interviews.

An inductive content analysis procedure was applied to interpret the data and to produce descriptive categories of the meanings from the research data. The questions were general in nature in order not to direct the responses. The main questions presented to the mentees were: What are the roles of mentors and mentees in a mentoring process? What kind of supports did you get from the mentor? What areas need improvement in the mentoring process? What are your recommendations for improving the mentoring quality? The interviews were encouraged to elaborate on each of the questions. However, having analyzed the content from the transcribed three-semi-structured group interviews, two main categories/themes were identified, namely, positive supports given to mentees in the process of mentoring and areas which need improvement for better mentoring supports of school principals.

This research was conducted with research ethics, particularly when collecting data and disseminating research results [11]. Therefore, prior to conducting interviews, permission for conducting interviews was asked to mentees. Respondents were free to choose if they did not want to participate in this study.

The study has limitations to generalize the findings since it did not represent respondents from every province in Indonesia.

\section{Results}

The following section highlights the findings of the study. The discussion of the findings was guided with two 
identified themes: mentoring supports given to mentees in the process of OJL, and areas need improvement for better mentoring of school principals.

\subsection{Supports in the Process of Mentoring}

Primary school mentors primarily supported the OJL implementation in personal development. They facilitated and supported all needs of the prospective principals. One prospective principal quoted what his mentor said, "Just carry out the OJL task, ma'am, you can take all documents that you need at school. Anytime you need me to sign in, I am here."

One of the primary school mentors played his role in motivating his mentee as he saw his mentee worrying of becoming a school principal, as quoted: "If I were promoted as a school principal, I am worried of building a good rapport and team work with teachers at school." The mentor gave motivation and shared his experience as a school principal in building rapport and teamwork. "Don't worry, enter the world, be self confident, you can do it! First time coming to the school: introduce your self and say that you are there for the betterment of this school, and say that you will not be able to do it if all members of the school community do not move along with you. Try to win their hearts. But remember! listen, observe and read the world first before you act."

Another mentor of primary school even showed his commitment, taking his mentee himself to the second school in which he also had to learn. He spoke to the school principal that his mentee needed the school principal's guidance and advice in order that the mentee could learn optimally in the second school.

The mentoring process, especially in primary schools, was far from being evaluative. Based on this research, the approach used was collegial, collaborative and non-judgmental. The mentoring process was so collegial that surprisingly, some mentees of primary schools instead behaved like auditors-asking and checking the practices of mentors in schools while bringing instruments. The following quotes exemplify the way the mentee interacted with her/his mentor. One respondent asked his mentor, "How many times do you supervise teachers? Can I see the documents?" Another respondent added, "We asked questions while bringing instruments we were asked to fill in." Yet, based on the admittance of mentees, the mentors did not object to this behavior since they were very closed. However, the way the two mentees behaved when asking their mentors was unethical. Both mentors and mentees need to know the role of each and behaved properly.

Secondary school mentors primarily supported in professional knowledge and technical development. Most mentees of secondary schools and four primary schools verbally said that they were satisfied with their mentors. The satisfaction was due to mentors' mastery of school management, availability of all documents in schools, and guidance or advice given by mentors while mentees were running activities of OJL. These mentors supported mentees by giving suggestions on their action plans, for instance, in determining resource persons, materials and venues to hold a workshop; and in analyzing 9 aspects of managerial at their schools.

Further, another respondent said that the mentor showed him all supervision instruments and advised him on determining a junior teacher who was going to be supervised by the respondent, as quoted: "These are supervision instruments we usually used. Study by yourself first, if you have questions, ask me. If I may suggest a junior teacher you will supervise is teacher $A B$ since he is a very newcomer teacher. He needs a lots discussion with his senior." This mentor also guided his mentee in developing a school development plan.

Some secondary school mentors, despite they were very busy with their routines, were still committed to meet with their mentees, provided that there was a communication beforehand. It was revealed that most of these mentors had attended training for school principals. No wonder they had the same perception and understood what the mentees need.

\subsection{Mentoring Skills which Need Improvement}

Finishing the IN-1, mentees went back to school and reported their learning in IN-1 and their tasks for the next phase-OJL including their action plans. As explained above, primary school mentors primarily supported the OJL implementation in personal development since they were so warm and welcomed that any documents the mentees needed were given by mentors. Yet, supports from mentors had to be more than giving access to all school documents. Mentees expected the mentors to read and to validate the action plan [41]. Yet, one prospective principal quoted what his mentor said, "Ok, I agree to the action plan, just do it!" The action plan and learning of mentees seemed to belong to mentees solely.

Long [28] emphasizes that mentors must have clear planning with a systematic mindset. When mentees were asked if there was a mentoring program for their OJL learning, they looked confused about which program that was expected. After receiving explanations about the mentoring program, most of them answered that there was no specific mentoring program for their learning. Planning for mentoring has not yet been popular among the mentors and mentees. They did not know that mentors and mentees must develop a mentoring program consisting of their learning road map; learning goals which should be formulated together [41] and realistic timelines to complete the required professional development $[2,26,30]$. Yet, two of them argued that they had an action plan as their guidelines to conduct OJL tasks. The action plan included indicators, a range of activities and a time frame. The others nodded, agreed, and said that they all had an action 
plan. Unfortunately, among 4 tasks they were obliged to do in their school, only 1 task was formulated in the action plan in detail. 3 other tasks were only scheduled without any objectives and detailed activities.

Most mentors in primary schools listened to mentees well. Yet, some mentors especially in secondary schools were so busy that mentoring session was conducted in a short period of time. Since mentoring was only carried out in a short time, the mentors failed to demonstrate mentoring skills: listening and questioning. This finding is in line with the finding of some studies. One respondent felt not supported by the mentor since the mentor was too busy heading two schools, one of which was their school. The principal was only a substitute principal in their school, as quoted here. "I learnt alone, my mentor was heading two schools, he was too busy to guide and to discuss with me on OJL tasks.”

In mentoring session, the conversation tended to be question and answer sessions. Mentees asked, and mentors answered. The conversations did not encourage critical thinking since every question was directly answered by mentors (if the mentors knew the answers). Mentors should have listened and asked before giving constructive feedback.

The practice of some mentors as principals in schools did not reflect the expected standards. The mentors, especially from primary schools felt less able to guide prospective principals, even the mentors considered the mentees to understand the principals' tasks and competencies more than their mentors. Therefore, all assignments were left to prospective principals. As the result, prospective principals studied independently.

Further elaborated in the group interview, the mentors did not perform well because mentors lacked mastery of school management, especially 8 national standards of education, whereas mastery of management and leadership is critical for mentors as they must be a role model and must also direct mentees to improve technical competencies [13].

The frequency of mentoring services occurred verily in 3 months. The range was from twice until 20 times in 3 months. Most unsatisfied mentees had less mentoring.

\section{Discussion}

Johnson and Ridley [19] recognize warmth as a necessary condition for maximal mentee growth and development. Hobson and McIntyre [18] added that if mentoring is too evaluative or judgmental, the mentee would not be willing to reveal the areas which need improvement to the mentor. This would influence the relationship between mentor and mentee. Avolio, et.al., Hobson \& Malderez, and Liang \& Augustine $[3,17,26]$ strengthen that mentee could perform if there are no worries to fail. This study confirms that a warm and non-evaluative mentor indeed influenced the relationship between mentor and mentee. Mentees felt free to ask for suggestions and documents that they needed. The relationship between mentor and mentee was collegial.

Yet, as found in this research, only by being warm mentors could not optimize mentee growth. Mentors need to master professional knowledge and skills of leadership and managerial as professional development growth of mentees is also the responsibility of mentors [15]. This finding is in line with Rippon and Martin [35] stating that professional knowledge is one important characteristic of mentors.

To support mentee professional development as a prospective school principal, mentors also need to demonstrate good practices or performance as school principals. Dennen and Burner [9] offered shadowing in the process of mentoring in order that the experienced leader models and demonstrates the thinking processes, coaches, or mentors the learner; the learner reflects and assesses, articulates his/her reflection and explores the outcome. The study of Ensher, Thomas, and Murphy's [13] further shows that mentee needs a role model from mentors. Mentees learn from mentor's performance [11] as research finds that mentees learnt mostly from observing mentors' attitudes and behaviors (29,3\%), listening to mentors $(24,4 \%)$, and interacting with mentors $(17,1 \%)$. Observation and imitation strengthened mentees' skills [20].

This study confirms that mentees need a role of the model as a good school principal. Yet, most of the mentors failed to model their leadership and managerial due to their lack of competencies and poor performance as school principals. This condition influenced the learning of mentees in OJL. As described above, they did not optimally learn from their mentors.

All mentees said that mentors need to have training in order that they can scaffold mentee learning optimally. This finding is in line with that of Hobson and Malderez, Lejonberg et al., Thornton $[17,23,37]$ arguing that mentors who do not receive appropriate mentor training are more likely to face greater difficulties in the role.

In Indonesia, mentors were not selected and prepared to guide the mentees. The first mentor of prospective school principals is their school principals. There is no training for mentoring prospective principals. Most mentors even had not had competency training as school principals as the prospective school principals did. Only few of the mentors were well recruited in accordance to the regulation of the Ministry of Education. The data of 2018 shows that only $0.23 \%$ of school principals were prepared in Principal Preparation Program (PPP) since the commencement of Ministerial Regulation Number 28 Year 2010. These facts contributed to the school principal lack of self-confidence with mentor the prospective principals.

As depicted in the result above, most mentors in primary schools listened to the mentees well. They seemed 
to have more time for their mentees, different from most of those in secondary schools who seemed to be so busy with their routines and activities, that listening and discussing with mentees were conducted in hurry. The finding in secondary schools in line with research shows that many schools do not allocate specific times for mentors and mentees to meet $[17,36]$. This finding also tells us that mentors and mentees seemed not really understand each other's roles and contributions in mentoring process. Therefore, there is a need to have a firm declaration of each mentor's and mentees' roles and contributions in mentoring [28].

Further, as depicted above, in mentoring session, the conversations between mentors and mentees did not encourage critical thinking since every question was directly answered by mentors (if the mentors knew the answers). The skills of questioning and providing constructive feedbacks of mentors need improvement. Mentors need to attend in-depth training on coaching or mentoring practices aimed to improve the skills of listening, asking questions, communicating positive things, and constructing feedback in a reflective, confidential, and safe environment [8]. Further, Lawrence [21] emphasizes that mentors need to guide mentees to find answers by themselves, not to give mentees the answers. Constructive questions from mentors can elaborate the critical thinking of mentees. Therefore, quality mentoring session is to be conducted in proper duration. $\mathrm{Ng}$ [29] argues that mentoring/coaching sessions can vary between half an hour and two hours. This style of mentoring is considered constructive and has been investigated as a developmental mentoring [34].

\section{Conclusions}

Based on this study, it can be concluded that mentoring supports for mentees of PPP need improvement. It appeared that mentors in primary schools were good at listening and being non-judgmental. Skills in encouraging critical thinking and giving constructive feedback are still far below standards. Another improvement for most primary school mentors is on professional knowledge development. Whereas, most mentors in secondary schools were good in terms of professional knowledge as school principals. Yet, they still need improvement in mentoring skills.

Obstacles which hampered the process of mentoring were 1) mentors' lack of time and information on the areas mentees needed to know. 2) some mentors were not mastering school administration, consequently, school administrative documents were not complete and there was no feedback after mentees conducted their learning in OJL, and 3) some principals led two schools and some had too many agendas outside the schools.

The implication of this study is that mentors need to attend training. Considering the findings, suggestions for mentor training will be divided into two categories. 1) training for improving mentoring skills. Mentors attending this training will be those who have attended training on professional knowledge of leadership and managerial; 2) training for improving professional knowledge of leadership and management, plus training for improving mentoring skills. Mentors attending this training are those who still lack of professional knowledge of leadership and management.

Another implication is district education offices need to be involved to motivate and to ensure that mentors undergo the formal training seriously [26].

Further research on mentoring can expand this study because the respondents do not represent the overall population of prospective principals. Besides, similar studies can be conducted with prospective principals whose mentors are alumni of training for school principals assuming that mentoring quality might be better since they have been attending an 8-day training for school principals.

\section{Acknowledgements}

The authors are very grateful to the trainers of PPP for giving permission to conduct group interviews with prospective principals. We also would like to thank all respondents who participated in this research.

\section{REFERENCES}

[1] Analytical and Capacity Development Partnership. Evaluation Report of Principal Preparation Program, ACDP Indonesia, Jakarta, 2016.

[2] Armstrong, D. E. Transition to the role of principal and vice-principal study," available at: https://education-leaders hip-ontario.ca/en/resource/principal-and-vice-principal-tran sition-role/ (accessed 10 February 2019), 2014.

[3] Avolio, B., Avey, J. and Quisenberry, D., Estimating return on leadership development investment, Leadership Quarterly, Vol. 21 No. 4, pp. 633-644, 2010.

[4] Barber, M., Whelan, F., \& Clark, M. Capturing the leadership premium: How the world's top school systems are building leadership capacity for the future. Retrieved from http://mckinseyonsociety.com/downloads / reports/ Education/schoolleadership_final.pdf, 2010.

[5] Bauer, T.N., Bodner, T., Erdogan, B., Truxillo, D.M. and Tucker, J.S., Newcomer adjustment during organizational socialization: a meta-analytic review of antecedents, outcomes, and methods”, Journal of Applied Psychology, Vol. 92 No. 3, pp. 707-721, 2007.

[6] Braun V. \& Clarke V., Using thematic analysis in psychology. Qualitative Research in Psychology 3, pp.77-101, 2006. 
[7] Bryman, A. and Bell, E. Business research methods. Oxford university press, Oxford, 2007.

[8] Cheliotes, L. and Reilly, M., Coaching Conversations, Corwin Press, Thousand Oaks, CA. Council of Chief State School Officers (2008), Educational Leadership Policy Standards, ISLLC, Washington, DC., 2010.

[9] Darling-Hammond, L., Meyerson, D., LaPointe, M. and Orr, M., Preparing Principals for a Changing World: Executive Summary, University Educational Leadership Institute, Stanford University, Stanford, CA, 2007.

[10] Dennen, V.P. and Burner, K.J., The cognitive apprenticeship model in educational practice”, in Spector, J.M., Merrill, M.D., Van Merriënboer, J. and Driscoll, M.P. (Eds), Handbook of Research on Educational Communications and Technology, Erlbaum, Mahwah, NJ, pp. 425-439, 2007.

[11] Denscombe, M., The Good Research Guide: For Small-Scale Social Research Projects. (2nd edition), Open University Press, Buckingham, 2003.

[12] Duncan, H. and Stock, M., Mentoring and coaching rural school leaders: what do they need?, Mentoring \& Tutoring: Partnership in Learning, Vol. 18 No. 3, pp. 293-311, 2010.

[13] Ensher, E.A., Thomas, C. and Murphy, S.E., Comparison of traditional, step-ahead, and peer mentoring on protégés' support, satisfaction, and perceptions of career success: a social exchange perspective", Journal of Business and Psychology, Vol. 15 No. 3, pp. 419-438, 2001.

[14] Hale, E.L., \& Moorman, H.N., Preparing school principals: A national perspective on policy and program innovations, Institute for Educational Leadership, Washington, DC, 2003.

[15] Hansford, B. and Ehrich, L.C., The principalship: how significant is mentoring?, Journal of Educational Administration, Vol. 44 No. 1, pp. 36-52, 2006.

[16] Hess, F.M., \& Kelly, A.M., Learning to lead? What gets taught in principal preparation programs, Harvard University, Kennedy School of Government, Cambridge, 2005.

[17] Hobson, A. J., and Malderez, A. Judgementoring and other threats to realizing the potential of school-based mentoring in teacher education", International Journal of Mentoring and Coaching in Education, vol.2, no. 2, pp. 89-108, 2013.

[18] Hobson, A.J. and McIntyre, J., Teacher fabrication as an impediment to professional learning and development: the external mentor antidote", Oxford Review of Education, Vol. 39 No. 3, pp. 345-365, 2013.

[19] Johnson, W.B., and Ridley, C.R., The Elements of Mentoring ( $3^{\text {rd }}$ edition), St. Martin's Press, New York, 2018.

[20] Lankau, M., J. \& Scandura, T.A., An Investigation of Personal Learning in Mentoring Relationships: Content, Antecedents, and Consequences. The Academy of Management Journal. Vol. 45, No. 4 (Aug., 2002), pp. 779-790, 2002.

[21] Lawrence, R., Executive mentoring: turning knowledge into wisdom", Business Strategy Series, Vol. 9 Iss 3 pp. $126-$ 131, 2008.

[22] Le Comte, L. and McClelland, B., An evaluation of a leadership development coaching and mentoring programme,
Vol.30, pp. 309-329, 2017.

[23] Lejonberg, E., Knut, E., E., Christophersen, A., "Mentor education: challenging mentors' beliefs about mentoring", International Journal of Mentoring and Coaching in Education, Vol. 4 Iss 2 pp. 142 - 158, 2015.

[24] Lester, P., Hannah, S., Harms, P., Vogelgesang, G. and Avolio, B. Mentoring impact on leader efficacy development: a field experiment", Management Department Faculty Publications, University of Nebraska-Lincoln, paper 80, available at:http://digitalcommons.unl.edu/management facpub/80, 2011.

[25] Levine, A., Educating School Leaders, The Education Schools Project, Washington, DC, available at: www.edschools.org/ , 2005.

[26] Liang, J. and Augustine-Shaw, D., Mentoring and induction for new assistant principals: The Kansas Educational Leadership Institute," International Journal of Mentoring and Coaching in Education, Vol. 5 No. 3, pp. 221-238, 2016.

[27] Lindgren, U., Experiences of beginning teachers in a school-based mentoring program in Sweden, Educational studies, Vol. 31 No. 3, pp. 251-263, 2005.

[28] Long, S. Mentoring: A Personal Reflection New Library World Volume 103· Number 1174· 2002· pp. 94 \pm 975 MCB UP, 2002.

[29] Ng Pak Tee, Grow Me!, Coaching for Schools, Pearson/Prentice Hall, Singapore, 2005.

[30] Oliver, R., Assistant principal professional growth and development: A matter that cannot be left to chance, Educational Leadership and Administration, Vol. 17, pp. 89-100, 2005

[31] Orr, M. and Orphanos, S., "How graduate-level preparation influences the effectiveness of school leaders: a comparison of the outcomes of exemplary and conventional leadership preparation programs for principals”, Educational Administration Quarterly, Vol. 47 No. 1, pp. 18-70, 2010.

[32] Pina, R., Cabral, I., \& Alves, J. M., Principal's leadership on students' outcomes. Procedia-Social and Behavioral Sciences, 197, 949-954, 2015.

[33] Rhodes, C. and Fletcher, S., Coaching and mentoring for self-efficacious leadership in schools,” International Journal of Mentoring and Coaching in Education, Vol. 2 No. 1, pp. 47-63, 2013.

[34] Richter, D., Kunter, M., Lüdtke, O., Klusmann, U., Anders, Y. and Baumert, J., How different mentoring approaches affect beginning teachers' development in the first years of practice”, Teaching and Teacher Education, Vol. 36, pp. 166-177, 2013.

[35] Rippon, J. H., \& Martin, M., What makes a good induction supporter? Teaching and Teacher Education, 22, 84-99, 2006.

[36] Stephens, S., Doherty, O., Bennett, B., and Margey, M. The challenge of work based learning: a role for academic mentors?", International Journal of Mentoring and Coaching in Education, Vol. 3, No. 2, pp. 158 - 170, 2014.

[37] Thornton, K., Mentors as educational leaders and change agents", International Journal of Mentoring and Coaching in 
Education, Vol. 3 Iss 1 pp. 18 - 31, 2014.

[38] Valentine, J. \& Prater, M., Instructional, transformational, and managerial leadership and student achievement: high school principals make a difference. NASSP Bulletin, 95(1), 5- 30, 2011.

[39] Wengraf, T., Qualitative research interviewing: Biographic narrative and semi-structured methods. Sage. London,
United Kingdom, 2010.

[40] Wildy, H. and Clarke, S., "Principals on L-plates: rear view mirror reflections", Journal of Educational Administration, Vol. 46 No. 6, pp. 727-738, 2008.

[41] Zachary, L.J., The Mentor’s Guide: Facilitating Effective Learning Relationships, Jossey-Bass, San Francisco, CA. 2012), 